\title{
PARTIAL TIME USE OF ANTERIOR REPOSITIONING SPLINTS IN THE MANAGEMENT OF TMJ PAIN AND DYSFUNCTION: A ONE-YEAR CONTROLLED STUDY
}

\author{
UTILIZAÇÃO DE PLACAS PROTRUSIVAS EM TEMPO PARCIAL NO TRATAMENTO DA DOR \\ E DISFUNÇÃO DA ATM: ESTUDO CONTROLADO DE UM ANO
}

\begin{abstract}
Paulo César Rodrigues CONTI ${ }^{1}$, João Evandro Silva MIRANDA ${ }^{2}$, Ana Cláudia C. Ferreira CONTI ${ }^{3}$, Luiz Fernando PEGORARO ${ }^{1}$, Carlos dos Reis Pereira de ARAÚ JO ${ }^{4}$
\end{abstract}

\begin{abstract}
1- DDS, PhD, Associate Professor, Department of Prosthodontics, Bauru Dental School, University of São Paulo, BRAZIL
2- DDS, PhD, Assistant Professor, Federal University of Pará, BRAZIL

3- DDS, MSc, Assistant Professor, Department. of Orthodontics, Paulista University, Bauru, BRAZIL.

4- DDS, PhD, Assistant Professor, Department of Prosthodontics, Bauru Dental School, University of São Paulo, BRAZIL.

Corresponding address: Dr. Paulo C. R. Conti (pcconti@fob.usp.br) - Bauru School of Dentistry, University of São Paulo Al. Otávio P. Brisola 9-75 - 17012-901 Bauru - SP - BRAZIL - Phone: 1432358340 - FAX : 1432358277
\end{abstract}

Received: December 8, 2004 - Accepted: March 18, 2005

\begin{abstract}
7 .

Lhis study aimed at evaluating the effectiveness of partial use of anterior repositioning appliances in the management of TMJ pain and dysfunction when compared to stabilization splints and a control group in a one-year follow-up. Sample was initially constituted by 60 patients, randomly divided into three groups: I- stabilization splints, II- repositioning splints and IIIno treatment. The whole sample was evaluated by means of TMJ and muscle palpation, mandibular AROM, analysis of occlusal contacts, joint sounds inspection and Visual Analogue Scale (VAS) for one year; 52 patients composed the final sample. A significant (after 15 days) improvement in pain report (VAS) and palpation index was found for group II ( $\mathrm{p} \leq 0.01$ ). The occurrence of occlusal alterations as posterior open bite or gross interferences after the splint therapy and increased muscle tenderness were not problems in this study. Similar results in joint noises reduction were observed for the entire sample. It was concluded that controlled partial use of repositioning splints is a beneficial tool in the management of intra-articular pain and dysfunction, with no risks of irreversible occlusal changes.

Uniterms: Temporomandibular joint; Occlusal splints; Occlusion.
\end{abstract}

\section{RESUMO}

O

objetivo desse estudo foi avaliar a efetividade das placas oclusais reposicionadoras no controle de patologias intraarticulares da ATM, quando comparadas a um tratamento convencional (placa estabilizadora) e um grupo sem tratamento (controle). A amostra final constou de 52 pacientes portadores de sinais e sintomas de desordens intra-articulares da ATM, divididos, aleatoriamente em três grupos, de acordo com o procedimento empregado: grupo I ( $\mathrm{n}=20$ ), utilizou placa estabilizadora, grupo II $(n=18)$ utilizou placa reposicionadora e grupo III $(n=14)$, sem nenhum tratamento.Toda a amostra foi acompanhada durante um ano, sendo avaliada através de questionários anamnésicos, palpação muscular e da ATM, movimentação mandibular e detecção de sons articulares.Uma avaliação da condição oclusal também foi realizada nos diferentes períodos de exame. Os resultados demonstraram uma maior efetividade das placas reposicionadoras na redução inicial da dor relatada pelo paciente, assim como uma diminuição na sensibilidade a palpação na ATM.Todos os grupos mostraram-se semelhantes após seis meses de controle em relação aos sintomas, assim como em relação aos ruídos articulares. Os índices de palpação muscular mostraramse melhor para todos os grupos, sendo que a oclusão também não se alterou significantemente. Baseado no acima exposto, conclui-se que a terapia de uso parcial das placas reposicionadoras constitui-se num meio efetivo de controle das patologias intra-articulares da ATM.

Unitermos: Articulação temporomandibular; Placas oclusais; Oclusão. 


\section{INTRODUCTION}

Temporomandibular Disorders (TMD) embrace a series of signs and symptoms involving the Temporomandibular Joint (TMJ), masticatory muscles or both ${ }^{18}$.

TMJ internal derangements constitute one of the most common findings in TMD patients. Joint sounds, pain and abnormal mandibular movements are frequently reported symptoms by those individuals. Although found in approximately $30 \%$ to $35 \%$ of an asymptomatic population, disc displacements are associated with pain and dysfunction in almost $80 \%$ of patients ${ }^{21,29}$, which raises a question about the real relationship between disc displacements and joint pain and/or dysfunction.

Strongly recommended in the past, the reestablishment of a "normal" condyle/disc relationship as part of a treatment protocol has been discussed, based on studies that demonstrated the capacity of the TMJ to adapt into a pain free condition, even with displaced $\operatorname{disc}^{22,23}$. This reestablishment and the "permanent" recapturing of the disc used to be achieved by different methods, including mandibular orthopedic repositioning appliance (MORA) followed by full mouth rehabilitation and orthodontic protocols $^{8,28}$. Open TMJ surgery with permanent disc suture to condyle also used to be a form of treatment for painful joints refractory to conservative strategies. Another protocol recommended the use of protrusive splints followed by a gradual return to the original intercuspal position in order to bring the disc back to the top of condyle ${ }^{19}$. High levels of relapse and return of symptoms were, however, very frequent ${ }^{12,13}$, which directed researchers to reconsider the need for a reconstructive phase II therapy ${ }^{30}$.

As a part of this scenario, the use of occlusal splints to control joint pain and/or sounds has become very popular worldwide. Flat stabilization appliances and protrusive ones are described as useful tools in the management of these patients, although most conclusions are based on short-time evaluations ${ }^{6}$.

What is the real benefit of repositioning splints and possible harm to dental occlusion or stimulate muscle disorders and pain is still a matter of controversy.

Based on that, this study aimed at assessing the effectiveness of partial use of anterior repositioning splints in the management of patients with TMJ intra-articular disorders, including pain and sounds, when compared to a group wearing stabilization splints and a control group in a one-year period. Indeed, the occurrence of possible secondary effects was also addressed, including muscle symptoms and dental occlusion alterations.

\section{MATERIALAND METHODS}

\section{Sample}

The sample was initially constituted of 60 patients, with complaints of TMJ pain presented to treatment at the Orofacial Pain Clinic at Bauru Dental School, University of São Paulo, Brazil. Inclusion criteria were the presence of TMJ disc displacement with reduction and chief complaint of pain in the joint followed by positive TMJ tenderness to manual palpation, accompanied or not by muscle symptoms. The presence of at least a clicking joint during opening, eliminated on opening in protrusion was also an inclusion criterion. Exclusion criteria were the presence of systemic diseases (i.e. rheumatoid arthritis, osteoarthritis, etc.), history of recent trauma or previous TMJ surgery. All groups were initially matched for gender and age and, after having filled out a consent form to participate in this study, subjects were randomly located into one of the following groups:

\section{Group I- stabilization splints}

Nocturnal wear was recommended for the period of one year. Design of these appliances included bilateral, simultaneous, posterior contacts, anterior and canine guidance, with full disocclusion of posterior teeth.

\section{Group II- repositioning splints}

Protrusive splints were used at nighttime for three to four months and then converted into stabilization splints, continuing its use until completion of the one year period. The degree of protrusion was the minimum necessary to eliminate joint clicking or to edge to edge position, when TMJ sound was absent.

\section{Group III- no treatment}

Control group, with no treatment or initial counseling.

The mean age of the whole sample was 31.8 years (32.7, 31.4 and 31.1 for groups I, II and III, respectively).

\section{Evaluations and follow-up visits}

The whole sample was evaluated by means of standardized TMJ and masticatory and cervical muscle palpation $^{18,20}$ (superficial and deep masseter; anterior, medium and posterior temporalis; insertion of medial pterygoid; upper trapezius and sternocleidomastoid) performed by one previously calibrated researcher, blinded for group distribution. The presence of joint noises and joint pain were detected during TMJ palpation, performed bilaterally in the TMJ lateral and posterior aspects. Muscle palpation was also performed bilaterally and simultaneously, with a digital pressure of $1.5 \mathrm{Kg}^{18,20}$. Analysis of mandibular active range of motion (AROM), joint sounds inspection and occlusal evaluation were also done. Level of pain report was measured by means of a Visual Analogue Scale (VAS), ranging from 0 to $100 \mathrm{~mm}$. After initial evaluation, follow-up visits were performed 1 week, 2 weeks, one, three, six months and one year after insertion of appliances. For different reasons, 8 patients ( 2 from group II and 6 from the control group) were excluded.

\section{Statistical analysis}

Repeated measurements ANOVA, two-way ANOVA, Kruskal-Wallis and McNemar's tests accounted for the statistical analysis for different variables involved in this study. A 95\% level of significance was applied and post-hoc tests were used to detect group differences, when necessary. 


\section{RESULTS}

\section{Report of pain and TMJ/ muscle palpation}

Analysis within groups and between groups was performed for this variable.

Results have shown a significant decrease in pain levels for all groups studied. For the whole sample, VAS decreased from $46.8 \mathrm{~mm}$ (sd $28.7 \mathrm{~mm}$ ) to $3.3 \mathrm{~mm}$ (sd $8.6 \mathrm{~mm}$ ) after one year.

In Table 1 and Figure 1, the progress of VAS figures within groups along the seven different examinations is represented. A significant and earlier (after 15 days) improvement in pain report could be found for Group II ( $\mathrm{p} \leq$ 0.01). Note that, after a period of 6 months, a statistically significant pain reduction has taken place for the entire sample, when joint pain was considered.

The analysis between groups also confirmed a statistical difference at the 15-day evaluation for Group II ( $\mathrm{p} \leq 0.01$ ), as seen in Table 2.

When the results of TMJ palpation were considered, a significant decrease in tenderness to palpation was observed after one, three and six months for Groups II, I and III, in that order $(\mathrm{p} \leq 0.01)$.

In Table 3, "p" values for comparison within groups between initial visit and follow-ups for the presence of TMJ painful sites to palpation are shown (McNemar's test).

Muscle palpation detected at least one painful spot in $34.62 \%$ of the whole sample at the beginning of the research, with a significant improvement after one year.

\section{Presence of joint noises/ mandibular range of motion}

When analyzing the progress of joint noises, similar results could be found for all groups, with a general reduction, judged by means of manual inspection, after one year, although not significant for the control group $(\mathrm{p}=0.13)$. For groups I and II, joint noises were no longer present after one year in $37.5 \%(\mathrm{p}=0.04)$ and $46.6 \%(\mathrm{p}=0.02)$, respectively.

Maximum active opening and excursive movements have also significantly increased for all groups after one year ( $\mathrm{p} \leq$ $0.01)$.

TABLE 1- Mean VAS figures (mm) for different groups

\begin{tabular}{llllllll}
\hline Group & Initial & $\mathbf{7}$ days & 15 days & 1 month & $\mathbf{3}$ months & $\mathbf{6}$ months & $\mathbf{1}$ year \\
\hline I & 52.75 & 49.5 & 43.2 & 30.3 & 18.5 & 3.5 & 4.55 \\
II & 40.27 & 27.00 & 18.6 & 7.5 & 3.3 & 1.6 & 1.66 \\
III & 47.50 & 39.2 & 30.3 & 25.4 & 15.0 & 2.8 & 3.92 \\
\hline
\end{tabular}

TABLE 2- Analysis between groups (Kruskal Wallis test) for pain report

\begin{tabular}{llllllll}
\hline Exam. & Initial & $\mathbf{7}$ days & $\mathbf{1 5}$ days & 1month & $\mathbf{3}$ months & $\mathbf{6}$ months & $\mathbf{1}$ year \\
\hline "p" & 0.385 & 0.052 & $0.002^{*}$ & $0.003^{*}$ & $0.005^{*}$ & 0.531 & 0.311 \\
GIXGII & $\mathrm{ns}$ & $\mathrm{ns}$ & $*$ & $*$ & $*$ & $\mathrm{~ns}$ & $\mathrm{~ns}$ \\
$\mathrm{GI}$ xGIII & $\mathrm{ns}$ & $\mathrm{ns}$ & $\mathrm{ns}$ & $\mathrm{ns}$ & $\mathrm{ns}$ & $\mathrm{ns}$ & $\mathrm{ns}$ \\
GIIxGIII & $\mathrm{ns}$ & $\mathrm{ns}$ & $*$ & $*$ & $*$ & $\mathrm{~ns}$ & $\mathrm{~ns}$ \\
\hline
\end{tabular}

ns - non-significant

*significant GI, GII, GIII - groups I, II and III.

TABLE 3- Analysis within groups for the presence of TMJ painful sites to palpation ("p" values)

\begin{tabular}{llll}
\hline & Group I & Group II & Group III \\
\hline 1 month & 0.130 & $0.010^{*}$ & 0.074 \\
3 months & $0.040^{*}$ & $0.004^{*}$ & 0.100 \\
6 months & $0.020^{*}$ & $0.003^{*}$ & $0.020^{*}$ \\
1 year & $0.040^{*}$ & $0.009^{*}$ & $0.020^{*}$ \\
\hline
\end{tabular}

* - significant

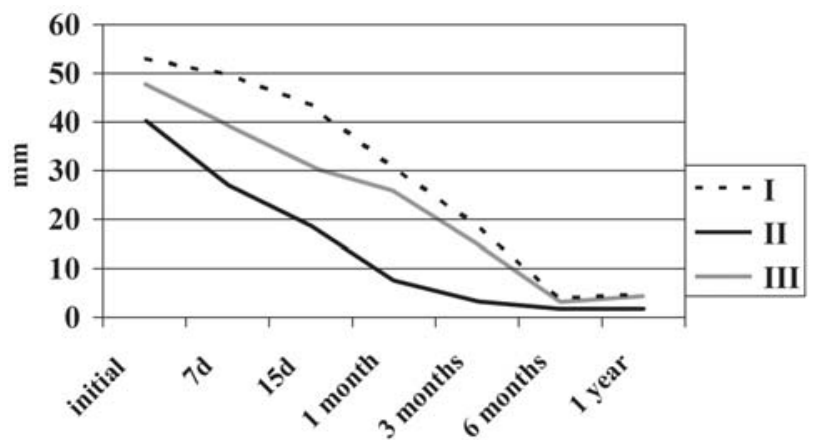

FIGURE 1- Pain report evaluation for different groups 


\section{Occlusal analysis}

A significant increase in the number of occlusal contacts was found for all groups ( $\mathrm{p} \leq 0.01)$. However, the analysis between groups has shown no differences $(\mathrm{p}=0.13)$. A mean of 26.9 occlusal contacts were found initially and 29.9 contacts after one year, considering the whole sample.

\section{DISCUSSION}

Several methods have been proposed as part of the management of TMJ pain and dysfunction, including physical therapy, pharmacotherapy, counseling, and occlusal treatment. Based on its non-invasive and conservative features, occlusal splints are an important part of these occlusal therapies ${ }^{16,20}$. Although extensively studied, the usefulness of this modality in recapturing the disc, decreasing pain and eliminating joint clicking, as well as an ideal design and wearing protocol have not been established so far $^{2,3}$. The concept of "evidence-based dentistry", very well accepted in the modern dentistry, has, however, resulted in a new perspective in the field of pain and dysfunction.

In the present paper, the establishment of specific inclusion criteria, the presence of a control group and longterm evaluations are important when judging results.

For a better understanding, this discussion is divided into different parts.

\section{Joint pain and mandibular motion}

Initial VAS figures were not significantly different between groups, which is important as part of the statistical protocol. When considering the analysis within groups, an earlier improvement in pain report was found for the protrusive splint group. These findings agree with several studies in which a repositioning splint provided significant improvements. In a recent study, Kurita, et al. ${ }^{11}$ have described successful disc recapturing in displacements with reduction. Presence of inflammatory process and morphological alterations of the disc were believed to be the reason for failure in cases of displacement without reduction.

Patients wearing protrusive splints reported significant improvements 15 days after the insertion of appliance. For groups I and III, however, a significant improvement has taken place only after 6 months. This condition remained unchanged for the rest of the year.

Considered in the past as an important method to recapture the disc, repositioning splints are also used only to decrease TMJ symptoms. The better and earlier result found for this group may be due to a decreased overload to retrodiscal tissues, allowing healing to occur. The maintenance of a normal disc/condyle relationship and/or a reduced joint pressure at nightime could, therefore, provide protection to structures previously damaged secondary to disc displacement. Sindelar, et al. ${ }^{25}$ have found increased thickness of posterior band of miniature female pigs after wearing splints for two months. Remodeling of the disc is also suggested as a result of splint wearing ${ }^{26}$. The decompressing effect of such tools, however, has been questioned recently ${ }^{10}$. Daytime functional activities, on the other hand, could stimulate the formation of a retrodiscal fibrosis and the establishment of a pseudodisc ${ }^{14,22}$. In the present study, after a period of initial use of protrusion, splints were transformed into stabilization splints at once, although a gradual return to an intercuspal position had been proposed in the past ${ }^{19}$.

Although it is widely accepted that most disc displacements will remain stable and asymptomatic, they are present in painful joints in almost $80 \%$ of cases $^{21,29}$. Permanent recapturing of the disc was not the goal of the temporary and partial use of a protrusive splint in this study. The exact disc position after one year could not be established, since an MRI image was not part of this study.

The delayed pain reduction for Groups I and III after six months may be the result of a slower healing process. The improvement for the control group characterizes the benign aspect of these conditions and warns about the need for irreversible procedures. This statement supports conclusions of Minakuchi, et al. ${ }^{15}$ in which patients with no treatment had similar outcomes when compared to the treated.

The improvement in range of motion for all groups in the present investigation is probably the result of decreased joint pain, associated with the recovery of possible secondary muscle co-contraction.

\section{Joint sounds}

One of the most frequent complaints in TMD patients is the presence of "joint noises". Although found more frequently in TMD patients, part of asymptomatic population has this complaint, with no need for any type of treatment ${ }^{11,18}$.

Joint sound has been thought to originate from ligament problems, excessive changes on the disc anatomy and joint fibers ${ }^{1}$, and changes on disc position related to mandibular movement. Anterior repositioning splints are described as a management strategy for clicking joints ${ }^{27}$, with reports of success in reciprocal clicking patients, as well as to decrease muscle fatigue ${ }^{12}$.

The possible progression from disc displacements and clicking joints to degenerative changes ${ }^{7,17}$ has led many clinicians to perform disc recapturing therapies as prevention. Some other authors ${ }^{4,5}$, however, found out that patients with condilar hypermobility and reciprocal clicking (displaced disc) did not present more degenerative changes than hypermobile joints that did not present clicking.

Yet, degenerative changes were found in normal disccondyle joints, raising the idea that disc displacement might be a consequence of underlying bone alterations ${ }^{5}$. Although sometimes successful in reducing joint sounds in anecdotal reports, splints are no longer used for this purpose. In the present moment, one can accept disc displacement and clicking maintenance after therapy, as long as joint pain and dysfunction have been resolved. In the present study, considering the whole sample, there was a significant sound reduction after one year $(\mathrm{p}<0.01)$, although not significant for the control group. 
The resolution of clicking is probably due to morphological alterations in the disc itself, especially in its posterior region, eliminating the physical obstruction for translation, and consequently decreasing the sound. This affirmation, however, would require more sophisticated diagnostic tolls, set as "gold standard", such as magnetic resonance image (MRI), not used in the present study.

\section{Muscle pain}

The improvement in muscle tenderness to palpation could express a recovery in TMJ condition, which would inhibit protective contraction and associated pain. This finding speaks against the proposition that repositioning splints might induce muscle pain.

Sfondrini, et al. ${ }^{4}$ attribute this occurrence to a change in the muscle fibers composition, leading to a "myoplasticity" adaptation process.

\section{Occlusal contacts}

Posterior open bites, occlusal alterations and intrusions are side effects commonly associated with the use of protrusive splints. ${ }^{1}$ Muscle contracture of lateral pterygoid and formation of a mass of posterior reparative connective tissue are though to be part of these alterations. Partial use of a full coverage protrusive splint in the present study, however, did not significantly change the number of occlusal contacts and did not cause any skeletal problem.

The maintenance or a slight increase in occlusal contacts found in the present investigation can be the result of healing of a joint pain and associated inflammation, allowing the mandible to return to a stable and physiological position.

\section{CONCLUSIONS}

Authors concluded that partial and controlled use of repositioning splints might be very useful in the initial management of TMJ pain and dysfunction. Decreased internal pressure and relieve of retrodiscal tissues could account for this fact. Long-term evaluation, however, showed that most symptoms (pain and joint noises) seem to subside regardless of the group studied, which warns about the need of irreversible treatments after the initial improvement. Irreversible occlusal changes (mainly posterior open bite) and increased muscle pain (caused by the protrusive position) do not seem to be problems with the protocol used in this study.

\section{ACKNOWLEDGEMENTS}

This study was supported by CAPES - Coordenação de Aperfeiçoamento de Pessoal de Nível Superior - Brazilian Government.

\section{REFERENCES}

1- Boever JA. Functional disturbances of the Temporomandibular Joints. Oral Sci Rev. 1973;1:100-17.

2- Clark, GT. Treatment of jaw clicking with temporomandibular repositioning: an analysis of 25 cases. J Craniomand Disord. 1984;2:263-70.

3- Cohen HV, Baragona PM. Long -term orthopedic appliance therapy. Dent Clin North Amer 1991;35:109-21.

4- Conti PCR, Miranda JES, Araujo CRP. Relationship between systemic joint laxity, TMJ hypertranslation, and intra-articular disorders. Cranio 2000;18:192-7.

5- De Bont LGM, Boering G, Liem RS, Eulderink F, Westesson PL. Osteoarthritis and internal derangements of the Temporomandibular joint: a light microscopic study. J Oral Maxillofac Surg 1986;44:63443

6- Ekberg EC, Vallon D, Nilner M. Occlusal appliance therapy in patients with Temporomandibular disorders. A double-blind controlled study in a short-term perspective. Acta Odontol Scand. 1998;56:1228.

7- Eriksson L, Westesson PL. Clinical and radiological study of patients with anterior disc displacement of the Temporomandibular Joint. Swed Dent J. 1983;7:55-64.

8- Gokalp H, Turkkahraman H. Changes in position of the Temporomandibular joint disc and condyle after disc repositioning appliance therapy: a functional examination and magnetic resonance imaging study. Angle Orthod. 2000;70:400-8.

9- Grace M. Evidence-Based Dentistry: the relevance of evidence. Quintessence Int. 1998;29:802-5.

10- Kuboki T, Takenami Y, Orsini MG, Maekawa K, Yamashita A, Azuma Y, Clark GT. Effect of occlusal appliances and clenching on the internally deranged TMJ space. J Orofac Pain. 1999;13:38-48.

11- Kurita H, Ohtsuka A, Kurashina K, Kopp S. A study of factors for successful splint capture of anteriorly displaced temporomandibular joint disc with disc repositioning appliance. J Oral Rehabil. 2001;28:651-7.

12- Lundh H, Westesson PL, Tillistron B. Anterior repositioning splint in the treatment of temporomandibular joints with reciprocal clicking: comparison with a flat occlusal splint and an untreated control group. Oral Surg Oral Med Oral Pathol.1985;60:131-6.

13- Lundh H, Westesson PL, Kopp S. A three-year follow-up of patients with reciprocal temporomandibular joint clicking. Oral Surg Oral Med Oral Pathol 1988;63:530-3.

14- Mills DK, Daniel JC, Herzog S, Scapino RP. An animal model for studying mechanisms in human temporomandibular joint disc derangement. J Oral Maxillofac Surg 1994;52:1279-92.

15- Minakuchi H, Kuboki T, Matsuka Y, Maekawa K, Yatani H, Yamashita A. Randomized controlled evaluation of non-surgical treatments for temporomandibular joint anterior disk displacement without reduction. J Dent Res. 2001;80:924-8.

16- Mongini F, Ibertis F, Manfredi A. Long-term results in patients with disk displacement without reduction treated conservatively. Cranio. 1996;14:56-59.

17- Ogus H. Degenerative disease of the Temporomandibular joint in young adults. Brit J Oral Surg. 1979;17:17-26. 
18- Okeson JP. Orofacial pain. Guidelines for assessment, diagnosis and management. Chicago: Quintessence;1995.

19- Okeson JP. Long-term treatment of disc-interference disorders of the Temporomandibular joint with anterior repositioning occlusal splints. J Prosthet Dent. 1988;60:611-6.

20 - Pertes RA, Gross SG. Clinical management of temporomandibular disorders and orofacial pain. Chicago: Quintessence; 1995.

21 - Ribeiro RF, Tallents RH, Katzberg RW, Murphy WC, Moss ME, Magalhães ME, Tavano O. The prevalence of disk displacement in symptomatic and asymptomatic volunteers aged 6 to 25 years. J Orofac Pain. 1997;11(1):37-47.

22- Scapino RP. Histopathology associated with malposition of the human temporomandibular joint disk. Oral Surg Oral Med Oral Pathol. $1983 ; 55: 382-97$

23- Scapino RP. The Posterior Attachment: its structure, function, and appearance in TMJ imaging studies. Part 2. J Craniomand Disord Facial Oral Pain. 1991;5:155-66.

24- Sfondrini G , Regianni C, Gandini P, Bovenzi R, Pellegrino MA. Adaptations of masticatory muscles to a hyperpropulsive appliance in the rat. Amer J Orthod Dentofac Orthop. 1996;10:612-7.

25- Sindelar BJ, Edwards S, Herring SW. Morphologic changes in the TMJ following splint wear. Anatom Records. 2002;266:167-76.

26- Sindelar BJ, Evanko SP, Alonzo T, Herring SW, Wight T. Effects of intraoral splint wear on proteoglycans in the Temporomandibular joint disc. Arch Biochem Biophysic. 2000;379:64-70.

27-Summer JD, Westesson PL. Mandibular repositioning can be effective in the treatment of reducing TMJ disk displacement: a long-term clinical and MR imaging follow-up. Cranio. 1997;15:10720

28- Tallents RH, Katzberg RW, Macher DJ, Roberts CA. Use of protrusive splint therapy in anterior disk displacement of the Temporomandibular joint: a 1 to 3 year follow-up. J Prosthet Dent. 1990;63:336-41.

29- Tasaki MM, Westesson PL, Isberg AM, Ren YF, Tallents RH. Classification and prevalence of Temporomandibular joint displacement in patients and symptom-free volunteers. Amer J Orthod Dentofac Orthop. 1996;109:249-62.

30- Yatani H, Minakuchi H, Matsuka Y, Fujisawa T, Yamashita A. The long-term effect of occlusal therapy on self-administered treatment outcomes of TMD. J Orofac Pain. 1998;12:75-88. 